\title{
AN EARLY EMBRYO MODEL OF STERLET (ACIPENSER RUTHENUS) FOR THE ASSESSMENT OF LEAD EFFECTS
}

\author{
Cristina, R. T. ${ }^{*}$-BAroga, M. - GrozeA, A. -Mihailov, S. A. - Sirb, N. M. - Dumitrescu, E. - \\ MUSELIN, F. \\ Banat's University of Agriculture and Veterinary Medicine „, King Michael I of Romania” from \\ Timisoara (BUAVMT), 119, Calea Aradului, 300645 Timisoara, Romania \\ *Corresponding author \\ Romeo Teodor Cristina, DVM, PhD. BUAVMT \\ e-mail: rtcristina@yahoo.com,romeocristina@usab-tm.ro; phone/fax:+40-256-277-140 \\ (Received $5^{\text {th }}$ Apr 2018; accepted 27 $7^{\text {th }}$ Nov 2018)
}

\begin{abstract}
The objective of the study was to devise a $96 \mathrm{~h}$ test of sterlet embryos (Acipenser ruthenus) in order to evaluate if this species is suitable for water pollution investigation as an evaluation tool. Replicate concentrations of lead acetate were selected from 400, 200, 100 and $50 \mu \mathrm{gL}^{-1}$. Each mirroraquarium was filled with $10 \mathrm{~L}$ of lead acetate dilutions, excluding the control, the free sterlet embryos were inserted as follows: $50 /$ aquarium, i.e. $100 /$ concentration and control group). The fish were examined at time 0 , then at: $12,24,48,72$ and 96 hours, every change in behavior or in the body somatic was statistically analyzed, according to ANOVA (significant when $p<0.05$, or less). Evaluation revealed significant connection among the embryos length $(p<0.05)$, weight $(p=0.01 ; p<0.01)$ and the dead embryos proved the deleterious feature of lead at 400 and $200 \mu \mathrm{gL}^{-1}$. The main critical points were: the delayed resorption of the yolk sac; deformed tail; undeveloped eyes; massive haemorrhages; atypical / altered pigmentation and exitus observed at $12 \mathrm{~h}$. Although A. ruthenus is not considered as a standard subject in the pollution assays, it was observed that, changes can be applied for early fish stages as a parallel to other accepted tests.
\end{abstract}

Keywords: acute risk-assay, free-embryos, heavy metals, sterlet

\section{Introduction}

It is known that the group of vertebrates that respond without delay if the environment is polluted, as a result of the anthropogenic activities, is the fish. Pollutants of freshwater sources, through their risk potential, can affect the human and animal health. Plentiful risk-assays, guides and standards being conceived, validated, and applied today (ASTM, 1988).

In eco-toxicology and bio-medical field fish adults and those early stages are helpfully handled, in order to test various substances, from industrial pollutants to medicinal active substances (Braunbeck et al., 2005).

However, the benefit of using acute toxicity tests for fish is represented by the applicability to a wide range of substances, this methodology is also used to compare the sensitivity to other aquatic species (Schirmer et al., 2008; Bakos et al., 2013).

The advance of the toxicity tests is bringing new evidence about the toxicological effects upon various fish species and those evolutive stages. Thus, the acute embryo tests are useful because it offers a simply accessible low-cost choice, which can give accurate outcomes (McKim, 1977; Embry et al., 2010; Rácz et al., 2012).

The early-stages provide rapid results and can enable a large number of repetitions in a short time period, consequently increasing the availability and reproducibility of the results (Luckenbach et al., 2001; Lammer et al., 2009). 
In this intention, zebrafish (Danio rerio) was originally tested, due to the numerous benefits provided compared to other species of lab animals currently used in experiments (Chakraborty et al., 2009; De Oliveira, 2009; Hill et al., 2005; Kovács et al., 2015; McGrath and Li, 2008; Mosneang et al., 2014, 2015a; Scholz et al., 2008).

Our prior observations had revealed similarities between zebrafish and another species, the pikeperch (Sander lucioperca) (Mosneang et al., 2015b), this reinforcing the confidence that also other fish species could be successfully used in such kind of experiments. In this respect, we had started an initial study in Romania on the sterlet (Acipenser ruthenus, Class: Actinopterygii; Order: Acipenseriformes; Family: Acipenseridae) a valuable species from the sturgeon family (Reinartz, 2017).

An important reason of why Acipenser ruthenus was chosen for this study was, on the one hand, its nutritional importance (meat and caviar being highly appreciated), and on the other hand, the fact that this species is threatened with extinction in many countries of the Danube basin and Central Europe where sturgeon has been included on the IUCN red list as "vulnerable". (Gessner et al., 2010).

In the case of Acipenseridae sp. effects of heavy metals have been hypothesized / proven as possible / contributing factors for decline of sturgeon population anywhere in the world. Until now studies were done using the acute (96-h) and chronic toxicity tests for: copper $(\mathrm{Cu})$, cadmium $(\mathrm{Cd})$, zinc $(\mathrm{Zn})$, and lead $(\mathrm{Pb})$, in a family member of $A$. ruthenus, namely the white sturgeon (Acipenser transmontanus) enlisted also as threatened species in Canada and the United States (Calfee et al., 2014; Little et al., 2012, 2014; Vardy et al., 2014; Wang et al., 2014).

Lead as toxic marker, represents one of the most confirmed threats of the aquatic environment due to its deleterial potential on the fish species, including here the sturgeons, from hatching problems and embryos' malformation (Osman et al., 2007), metabolic imbalance, feeding alterations (Weber, 1996) and high mortality levels of juveniles (Hariharan et al., 2016).

In sturgeons lead and other aquatic pollutants certainly accumulate (Little et al., 2014; Raskovic et al., 2015; Subotic et al., 2013) affecting the spermatozoa quality (Linhartova et al., 2015) or generating adverse behavioral changes (Vardy et al., 2014; Wang et al., 2014).

In this aim, our reason was to provide information regarding the lead activity on sterlet embryos exposed to four different lead concentrations, in a static 96 hours acute toxicity test. The test was conceived as a simply replicable procedure, in the light of the known related methodologies and as a notable laboratory instrument for the contamination monitoring (OECD Test No. 203; OECD Test No. 210; OECD Test No. 236).

\section{Material and Methods}

OECD Tests No. 236 and 210 were adopted: 2013, acute risk-assays, were adapted for early stages of $A$. ruthenus. Our interest was to identify all the signs dependable with the lead acetate exposure, including here: general behavior, anatomical and morphological features and the survival rate at different concentrations of lead.

\section{The Test Substance and Concentrations}

The methodology for determining the acute toxicity substances in early stage or adult fish requires knowledge of the physico-chemical properties of the investigated 
substances, for the selection of the most appropriate test method (e.g. static, semi-static, or with continuous flow), in order to preserve the constant concentration of the test substance. In our study, the test substance was lead which was formed by solubilization of lead acetate $\left(\mathrm{C}_{8} \mathrm{H}_{12} \mathrm{O}_{8} \mathrm{~Pb}\right)$ Lead acetate (or Lead (IV) Acetate, $>=99.99 \%$ ) is a trace metal basis and the most soluble salt in water. This is the reason for using this salt in our in vitro study (and also by the majority of researchers in this research topic). In our test the pure lead concentration was essential and it is known that $1 \mathrm{mg}$ of lead acetate contains 54.622\% pure lead (Merck, Germany). Also all methodologies for OECD tests are using lead acetate. To cover the problems that could arise from testing metal toxicity without testing the chemical composition of the test waters we respected the requirements of Meyer et al. (2012), and serial dilutions were performed (Meyer et al., 2012; PubChem - SID 24864770).

For study duplicate concentrations from $400 \mu \mathrm{gL}^{-1}$ (400 ppb), $200 \mu \mathrm{gL}^{-1}$ (200 ppb), $100 \mu \mathrm{gL}^{-1}(100 \mathrm{ppb})$ and respectively $50 \mu \mathrm{gL}^{-1}(50 \mathrm{ppb})$ (representing the admitted limit for drinking water in the EU) were chosen (Directive 98/83/EC) (Table 1).

Table 1. Obtainment of lead acetate experimental concentrations

\begin{tabular}{l|l}
\hline \multicolumn{2}{l}{$\begin{array}{l}\text { Dilution in duplicate } \\
1 \mathrm{~g} \text { of lead acetate contains } 54.622 \% \text { pure lead }\end{array}$} \\
\hline $\begin{array}{l}\text { Concentration / Lead acetate / pure Lead } \\
\begin{array}{l}400 \mathrm{ppb}\left(400 \mu \mathrm{gL}^{-1}\right) \\
12.4 \mathrm{mg} \mathrm{lead} \text { acetate in } 20 \mathrm{~L} \text { water }\end{array}\end{array}$ & Successive dilutions \\
\hline $\begin{array}{l}200 \mathrm{ppb}\left(200 \mu \mathrm{gL}^{-1}\right) \\
\text { or } 6.2 \mathrm{mg} \mathrm{lead} \mathrm{acetate} \mathrm{in} 20 \mathrm{~L} \text { water }\end{array}$ & $1: 1$ dilution to $20 \mathrm{~L}$ \\
\hline $\begin{array}{l}100 \mathrm{ppb}\left(100 \mu \mathrm{gL}^{-1}\right) \\
\text { or } 3.6 \mathrm{mg} \text { lead acetate in } 20 \mathrm{~L} \text { water }\end{array}$ & $1: 1$ dilution to $20 \mathrm{~L}$ \\
\hline $\begin{array}{l}50 \mathrm{ppb}\left(50 \mu \mathrm{gL}^{-1}\right) \\
\text { or } 1.8 \mathrm{mg} \mathrm{lead} \mathrm{acetate} \mathrm{in} 20 \mathrm{~L} \text { water }\end{array}$ & $1: 1$ dilution to $20 \mathrm{~L}$ \\
\hline
\end{tabular}

After dilutions, no perceptible precipitates were present in none of the used dilutions. The water used for the experimental and control groups was a microbiologic pure bottled water (Aqua Carpatica, Romania), with a natural oligomineral content and with a balanced $\mathrm{pH}$ (7.0 to 7.2). This water is certified in Romania as being free of nitrates and nitrites and with no potentially dangerous concentrations (e.g. chlorine, heavy metals and other potentially harmful substances). To kill any microbiologic content, water was sterilized by ultraviolet (UV) radiation, at $254 \mathrm{~nm}$, for 10 minutes / five litre flasks. Consequently, water containing lead at the appropriate test concentrations was introduced into the test aquariums for 3 hours prior to the introduction of fish' early stages, to properly incorporate and stabilize the temperature at $18^{\circ} \mathrm{C}$ (which is the optimum growth temperature for the early stages of $A$. ruthenus).

\section{The Experimental Methodology}

\section{Experimental Aquariums and Free Embryos of Acipenser ruthenus}

The experimental acquariums and the juvenile sterlet sturgeon were provided by the Department of Fisheries from the Faculty of Animal Science Timisoara, Romania the parents being reared in Recirculating Aquaculture System (RAS). The artificial 
reproduction, egg incubation, and initial rearing of the free embryos were carried out in agreement with accepted methodologies for A. ruthenus (Chebanov and Galich, 2011).

The obtained sterlet free embryos were healthy, without somatic visible defects. Since this study started using hatched free embryos at two days of age (knowing that natural mortality in day one can reach approximately 50\%). Feeding was not necessary for the entire study period, knowing that the A. ruthenus free embryos start to feed commonly at 6 to 7 days of life, after their yolk-sac is absorbed (Chebanov and Galich, 2011).

During the study, the free embryos were kept in mirror glass aquariums of ten-liter capacity (two spaces / one concentration), with the embryos maintained for 96 hours in a static system, exposed to different lead test solutions.

Since the sturgeon early stages are extremely vulnerable organisms, the best possible maintenance was vital to be reproduced, to avoid the modification of the authentic experimental results. The room temperature was maintained at $18^{\circ} \mathrm{C}$, and the temperature in the aquariums, verified at each two hours was maintained at $18 \pm 1.2^{\circ} \mathrm{C}$. To preserve the optimum parameters, the room temperature registration was provided with a thermostat and freshening was assured with an air-conditioning system. In accordance with the measures necessary for testing and knowing that at this stage, sturgeon embryos are initialy negatively phototaxic, the daily photoperiod was maintained at $10 \mathrm{~h}$ light / $14 \mathrm{~h}$ dark, the temperature and the oxygen requirements, were appropriate for sturgeon early stages (air saturation provided oxygen levels; at 2-2.5 $\mathrm{mgO}_{2} \mathrm{~L}^{-1}$, and the temperature to not fluctuated more than $\pm 1.2^{\circ} \mathrm{C}$ ). The dissolved oxygen value was within the normal range from the first treatment day to the last, because the aeration introduction in each of the aquarium filters ensured the optimum level of oxygen above $70 \%$ to correspond with the aeration rate (Chebanov and Galich, 2011).

The samples were carried out in pairs (groups A and B) and each mirror-aquarium was filled with $10 \mathrm{~L}$ of water. After the acclimation period, the free embryos were inserted: 50 larvae / aquarium, i.e. 100 larvae / concentration as follows: E1A, E1B / $400 \mu \mathrm{gL}^{-1}$; E2A, E2B / $200 \mu \mathrm{gL}^{-1}$; E3A, E3B / $100 \mu \mathrm{gL}^{-1}$; E4A and E4B / $50 \mu \mathrm{gL}^{-1}$. The control group $(\mathrm{C})$ consisted of 100 healthy larvae.

\section{The Free Embryos Examination}

Sterlet free embryo specimens were monitored at the examination time 0 and then, at 12, 24, 48, 72, and 96 hours (one hour / read). From the start of each examination, every behavioral change or alteration in the somatic body was noted. The measurements included the individual weighing, the total length, pre-anal length, and total height of the larva, and these were carried out according to the scheme shown in Figure 1.

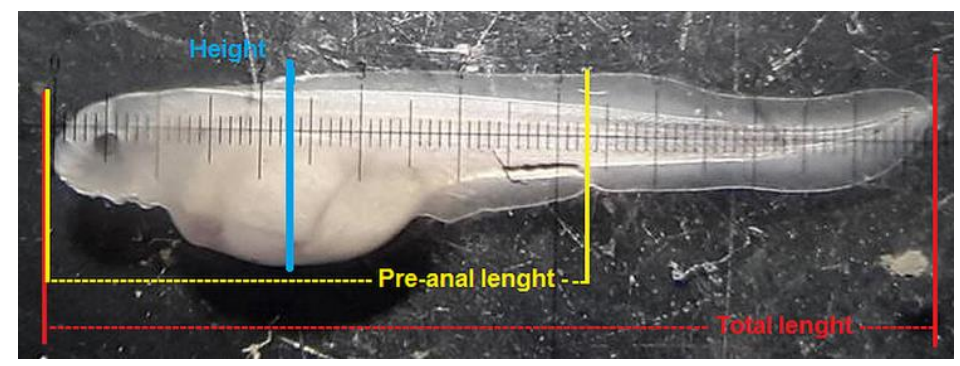

Figure 1. Scheme of starlet sturgeon free embryo measurement 
At the onset of the study, at day two after hatching, the initial measured average length of a sterlet free embryo was of $9.7 \mathrm{~mm}$ (all embrios being normal, showing small eyes, nose openings, well developed fin folds and yolk sac) and the individual body weight ranging from 0.191 to $0.195 \mathrm{~g}$. The main toxicity critical points were observed in conformity with the OECD instructions, presented in Table 2.

Table 2. Critical toxicity points according to OECD guidelines [OECD Tests No. 210 and 236: 2013]

\begin{tabular}{c|l}
\hline Crt. no. & Larvae somatic / behavioral changes \\
\hline 1. & Tail undetachment \\
\hline 2. & Arrhythmic heartbeat \\
\hline 3. & Edema or haemoragies in thoracic cavity \\
\hline 4. & Magnification of thoracic cavity / fluid accumulation \\
\hline 5. & Body pigmentation \\
\hline 6. & Tail in: V, L or S letter shape or unfinished growth \\
\hline 7. & Immobility / severe altered mobility / slow / rapid - alternative mobility \\
\hline 8. & Swimming: vertically or like propeller \\
\hline 9. & $\begin{array}{l}\text { A larva is considered dead if, it weren't gill movements observed and if touching the } \\
\text { caudal peduncle would not have registered any reaction }\end{array}$ \\
\hline
\end{tabular}

\section{Fish Anesthesia and Euthanasia}

To examine with minimal possible aggression, the vital and somatic changes, the temporary immobilization and afterwards, the free embryos euthanasia was carried out with tricaine mesylate (syn. Metacaine; Tricaine, MS-222; Finquel) (Merck, Germany) the substance accepted both in the EU and in the US for fish anesthesia / euthanasia. The substance (a white powder) was diluted to a concentration of $100 \mathrm{mgL}^{-1}$ (as anesthetic) and $500 \mathrm{mgL}^{-1}$ (as euthanasiant), for a contact period from 2 to 10 minutes (Science Direct Topics: Tricaine mesylate).

\section{Instrumentation}

The somatic changes of fish were observed under a Kruss model Optronic GmbH (Germany) microscope, using the $10 \times$ objective (WF10 $/ 20$ ), and the weight was assessed using a Sohn $\mathrm{GmbH}$ electronic balance (Kern ABJ 220-4M with $0.01 \mathrm{mg}$ error). The $\mathrm{pH}$, oxygen, and the water temperature were measured using a Hach HQ40D, portable analyzer, (Hach Products, Germany) (Figure 2).

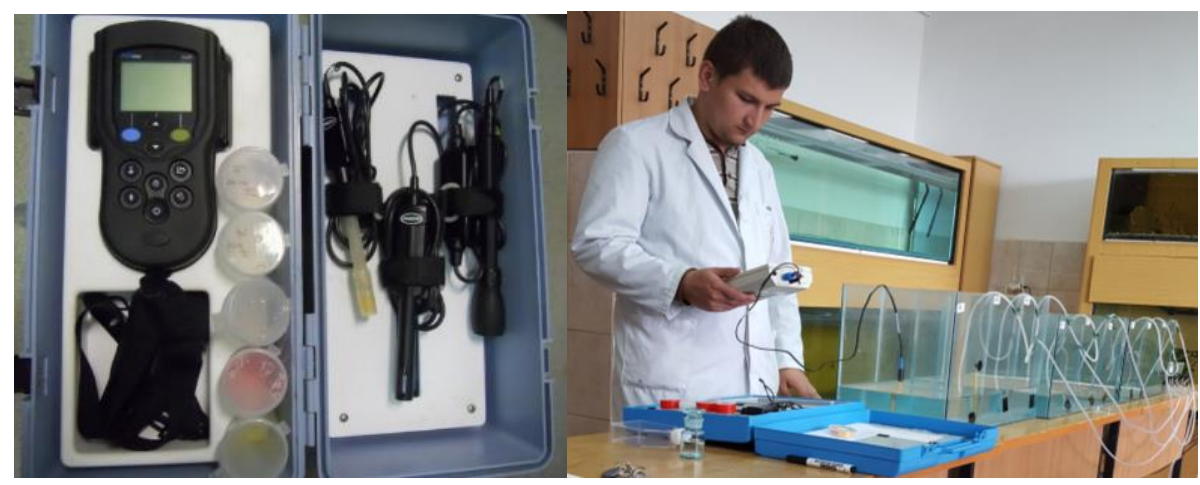

Figure 2. Portable analyzer, (Hach Products, Germany) used for measurements and research aquariums 


\section{Statistical Analysis}

The statistical values were analyzed as the mean (x), variance (s), CV (critical value), average (Sx and Sx \%), mean \pm SEM (mean's middle error), and were graphically expressed through the GraphPad Prism 6.0 for Windows (GraphPad, San Diego USA). For the evaluation of differences between the groups, the two-way ANOVA, with the $t$ test and respectively Bonferroni's multiple comparison test correction were conducted, the statistical difference being set at $p<0.05$ or lower.

\section{Results and Disscussion}

During the sterlet testing, two strong critical points were initially identified:

a) The attempt of the sterlet larvae to escape upon introduction into the tanks containing the highest concentration $\left(400 \mu \mathrm{gL}^{-1}\right)$.

b) The negative response of the sterlet larvae to swim and move after descending to the bottom of the aquarium, followed by the subsequent appearance of various behavioral disorders.

Sterlet larvae maximum mortality was observed at lead concentrations of 400 and $200 \mu \mathrm{gL}^{-1}$. The first dead larvae were detected after 12 hours of lead exposure, with the peak at 72-96 hours interval.

The main changes considered as critical points identified by us, which is evidence of the deleterious activity of lead including: delayed resorption of the yolk sac, deformed / modified tail, undeveloped eyes, massive haemorrages (cardiac / pericardial / peritoneal / general), abnormal / altered pigmentation and exitus.

Under the microscope, tail undetachment was also observed; the acute toxicity to the studied larvae being emphasized by the lack of tail posting, oversized abdomen, bleeding heart and / or absence of regular heartbeats. Compared with the control, the results disclosed different, but significant, statistical values registered for the average length parameters measured at 24 and 96 hours and for the main weight parameters at moment 0 and 96 hours per the experimental concentrations. Statistical evaluation revealed a significant association among the influence of lead to the length $(* p<0.05)$ and weight $(* * p=0.01 ; * * * p<0.01)$ parameters and respectively the number of dead sterlet larvae at the same concentration proving the deleterious activity of lead (Figure $3)$.

Analyzing comparatively with healthy larvae, the consequences of contact with the experimental solutions were observed mainly after 12 hours of exposure to lead. The main behavioral alterations were fast and erratic movements of larvae to the 400 and $200 \mu \mathrm{gL}^{-1}$ concentrations, manifested by corkscrew and circular type motions, irregular contractions, and stationary side position on the aquarium bottom. These low swimming performances were amplified over the course of the experiment and included heart haemorrages, distended abdomen, and tail in a V, L, or S shape etc. (Figure 4).

The greatest percentage of dead larvae was found after 96 hours in the case of the E1A / 1B and E2A / 2B treatments. In terms of the experimental parameters, the measured $\mathrm{pH}$ values were between 7.1 and 7.3 and the thermal curve was maintained into the comfort zone of the larvae until the final day of the test $\left(18\right.$ to $\left.19.2^{\circ} \mathrm{C}\right)$ (Figure $5)$. 


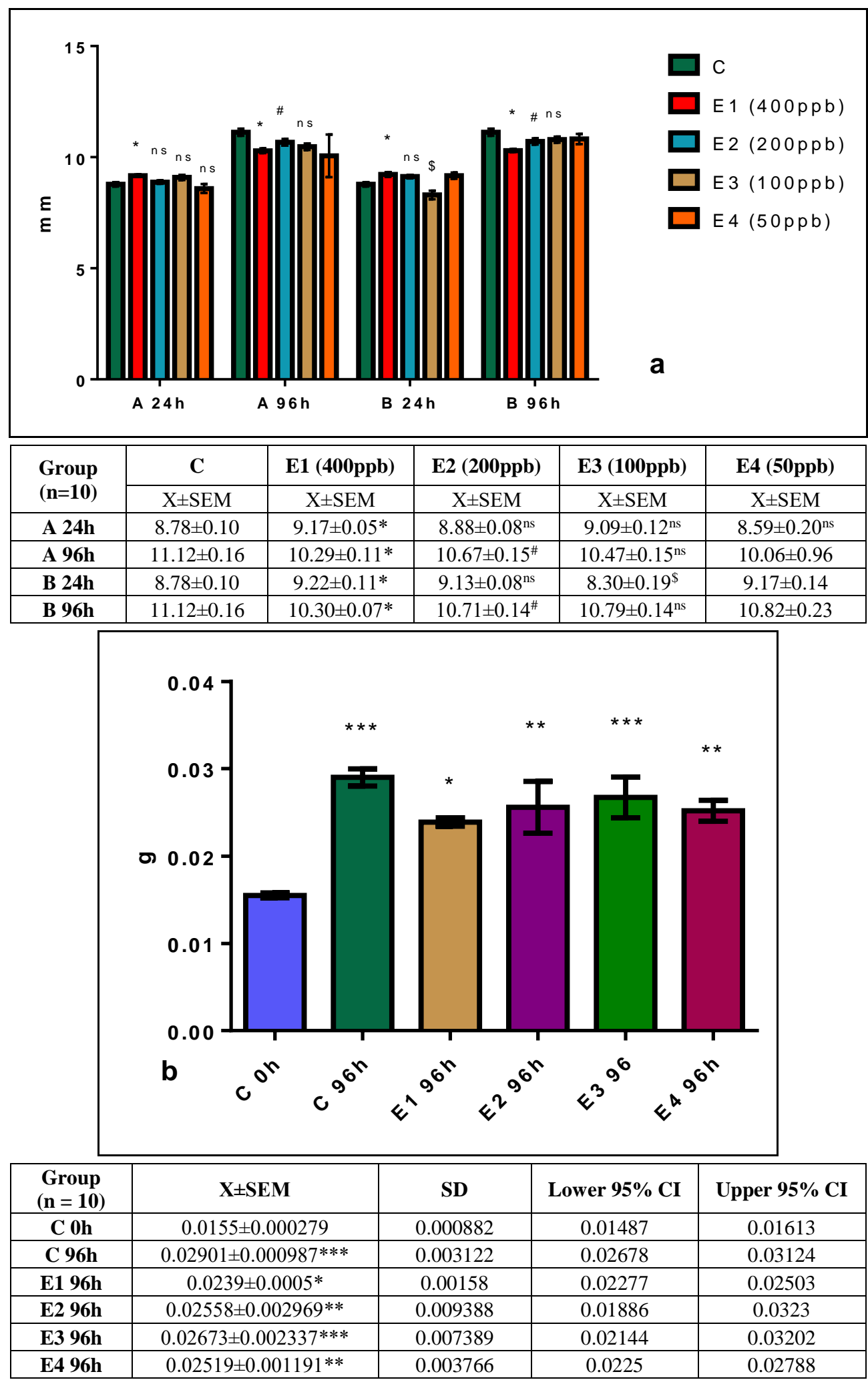

Figure 3. The evolution of the average length parameters at various lead concentrations at 24 and 96 hours of exposure (a) and the significance of the weight parameters at various lead concentrations at day 0 and 96 of exposure $(\boldsymbol{b})$

Where: $* p<0.05 ; * * p=0.01 ; * * * p<0.01$; \# comparative to Control $p<0.05 ; n s=$ not significant 


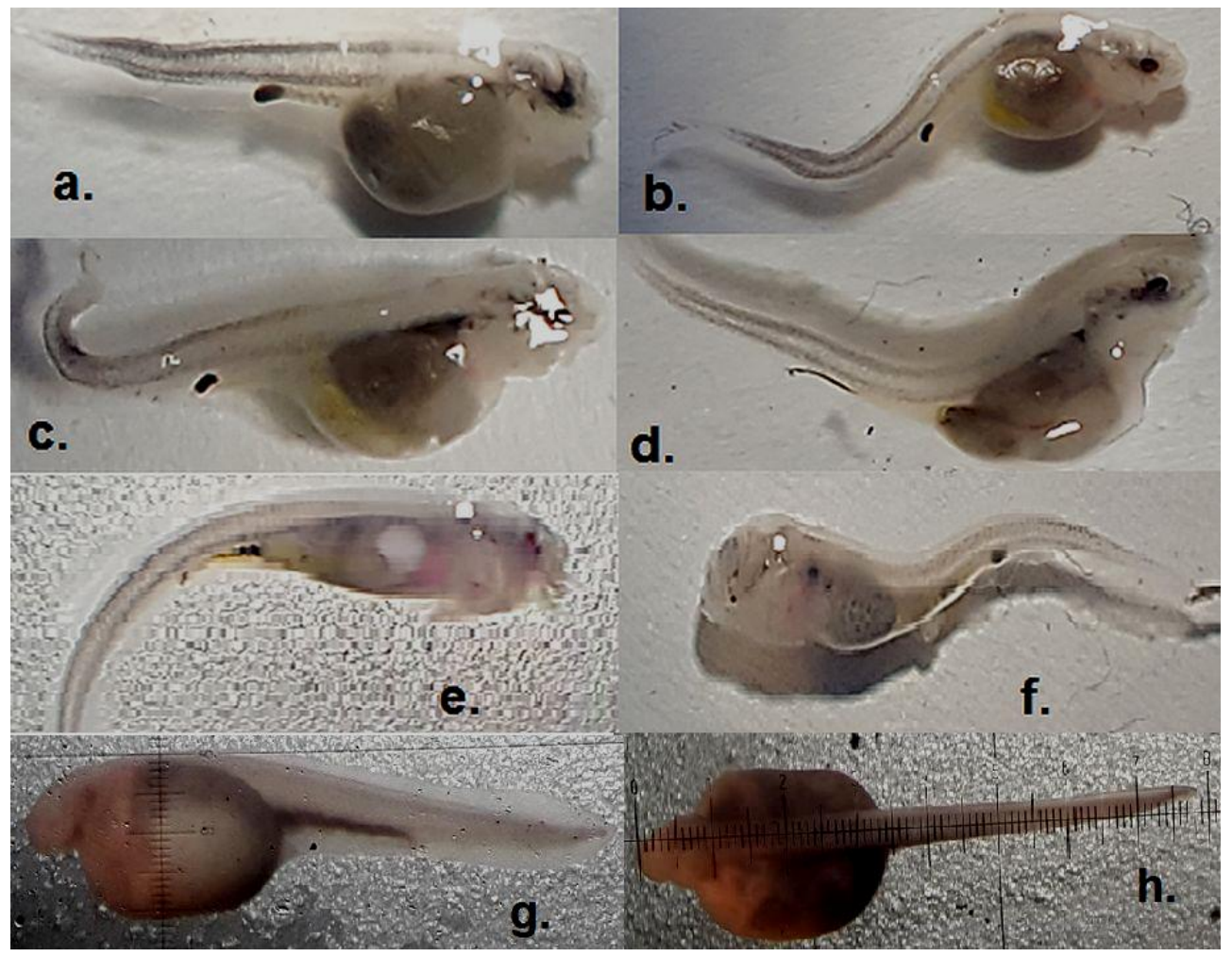

Figure 4. Structural abnormal features observed in starlet larvae exposed to lead: (a) delayed resorption of the yolk sac; (b) " $S$ " shape deformed tail; (c) hook shape tail; (d) " $V$ " shape spinal column; (e) less intense pigmentation, generalized hemorrhages; $(\boldsymbol{f})$ scoliosis, undeveloped eyes; comparative: healthy larve and scale (lateral $(\boldsymbol{g})$ and dorsal (h)

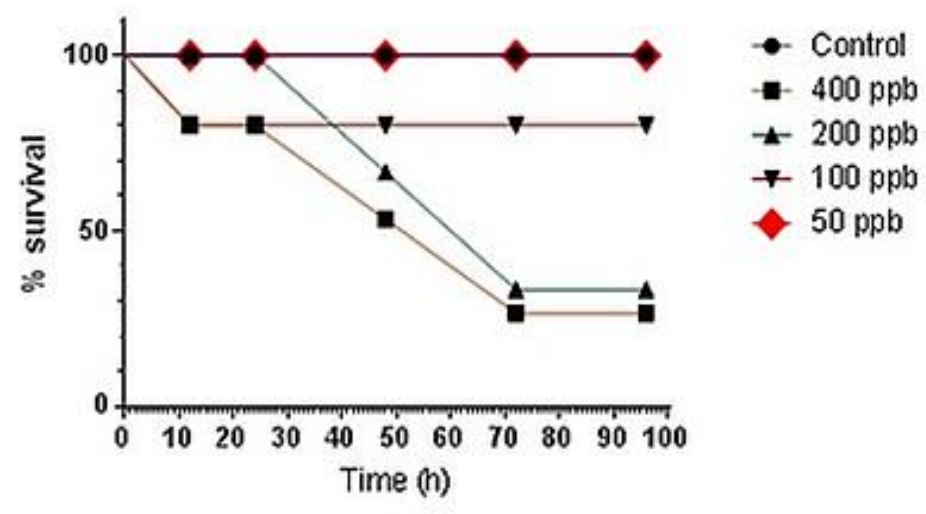

Figure 5. The survival rate / lead concentration during the test period

Initial studies have shown that fish are sensitive enough to detect pollutants in waters both in acute and long-term studies. More and more researchers are utilizing embryo and larval toxicity tests as alternatives to the adult fish acute or chronic toxicity tests, as these are reliable tools to assess the toxicity potential (Embry et al., 2010; Chakraborty et al., 2009; Scholz et al., 2008).

In this aim, in the last decade, studies on this topic were largely diversified, including here different species of sterlet sturgeon, bringing useful information, primarily related 
to the fields of environmental, aquatic, and reproductive toxicology for the species Acipenser transmontanus (Calfee et al., 2014; Little et al., 2012, 2014; Vardy et al., 2014; Wang et al., 2014), the data for Acipenser ruthenus are much more sparce (Raskovic et al., 2015; Linhartova et al., 2015).

We observed that the acute toxicity effects of miscellaneous sources, such as heavy metals (in our case), but also effluents, contaminants etc., is highlighted in the registered anatomical and ethological changes of sturgeon early stages (Calfee et al., 2014; Little et al., 2012). This is noteworthy, as it is a strong motivation why these fish categories are used in recent pollution hazard and risk assessments including here sturgeons (Vardy et al., 2014; Raskovic et al., 2015).

As a research alternative, we agree with authors who have assessed that fish could be completely complementary to rodents or other mammmals (especially in toxicology and drug research) (Schirmer et al., 2008; Embry et al., 2010; Chakraborty et al., 2009; De Oliveira, 2009) and we appreciate that with the development of present sterlet in vitro model, investigators will be able to replace and offer significant results about water toxicity which will be valuable also to vertebrate research. Based on this observation we noted also that sterlet sturgeon have appropriate features to conditions of temperate climate, making them a suitable candidate, as alternative for zebrafish embryos and larvae, in some specific experiments (eco-tox, embrionar, pollution) in this climate.

As a limitation, it should be pointed out that many aquatic toxicity experiments which have been published have the same shortcomings as the present study, with chemical exposures reported as expected concentrations actually without much more accurate measuring responses. But even if, the studied exposures to lead are not entirely well-known, this work demonstrates that the sterlet sturgeon could credibly be added to the list of the suitable organisms for toxicity tests.

The presence of the mentioned behavioral alterations (considered as critical control points and practically identical with those found in zebrafish), identified for the sterlet early stages are sustaining the results obtained, and consider the sterlet sturgeon as a possible new fish species that could be added to the already recognized and internationally accepted fish species (e.g. zebrafish, medaka, fathead minnow or trout) for the acute tests in the environmental toxicology.

In the favour of this, the analysis of biological damages in conjunction with other endpoints (mortality, external factors etc.) could help to the better interpretation of the effects of lead and could easily be extrapolated to other heavy metals (on sturgeon or other fish species to understand their populational decline), which means early identification of bioaccumulation present in this species (Raskovic et al., 2015; Noel et al., 2013; Waszak and Dabrowska, 2009).

It is also important to mention, that the methodology extrapolation to sturgeons is needed, given the notable scientific and economical importance of these unique natural resource, considered as a central, species in countries where the habitat of this species is located (Reinartz, 2017; Subotic et al., 2013).

The use of Acipenser ruthenus early developmental stages is beneficial, since fish embryos and larvae are exempt from animal protection laws. According to the European welfare regulations, this test is categorized as in vitro testing, and thus is not subjected to the animal protection legislation situation that, in our point of view, can be easily extrapolated to any fish larvae and further studies on different species (Directive 2010/63/EU). 


\section{Conclusions}

We consider that this method could be developed as an alternative assay, though the sterlet sturgeon (Acipenser ruthenus) is not yet considered as a standard in the assays for toxicology or pollution.

Data obtained could be useful to determine the critical concentration of a single or multiple contaminants that may cause sizeable consequences as environmental pollutants.

Acknowledgements. This study was conducted using the support and infrastructure of the project "Dezvoltarea infrastructurii de cercetare, educație şi servicii in domeniile medicinei veterinare şi tehnologiilor inovative pentru RO 05", code SMIS-CSNR 2669. Many thanks for Dr. Judit Házi for the valuable comments.

Conflict of Interests. The authors declare no conflict of interests.

\section{REFERENCES}

[1] ASTM (American Society for Testing and Materials) ASTM E1241-05. (1988): Standard Guide for Conducting Early Life-Stage Toxicity Tests with Fishes. - Available at: https://www.astm.org/Standards/E1241.htm (Accessed 12.12.2017).

[2] Bakos, K., Kovács, R., Staszny, Á., Sipos, D., Urbányi, B., Müller, F., Csenki, Zs., Kovács, B. (2013): Developmental toxicity and estrogenic potency of zearalenone in zebrafish (Danio rerio). - Aquatic Toxicology 136-137: 13-21.

[3] Braunbeck, T., Böettcher, M., Hollert, H., Kosmehl, T., Lammer, E., Leist, E., Rudolf, M., Seitz, N. (2005): Towards an alternative for the acute fish LC50 test in chemical assessment: the fish embryo toxicity test goes multi-species - an update. - ALTEX 22: 87-103. (PMID: 15953964).

[4] Calfee, R. D., Little, E. E., Puglis, H. J., Scott, E., Brumbaugh, W. G., Mebane, C. A. (2014): Acute sensitivity of white sturgeon (Acipenser transmontanus) and rainbow trout (Oncorhynchus mykiss) to copper, cadmium, or zinc in water-only laboratory exposures. - Environmental Toxicology and Chemistry 33: 2259-2272. Available at: http://dx.doi.org/10.1002/etc.2684.

[5] Chakraborty, C., Hsu, C. H., Wen, Z. H., Lin, C. S., Agoramoorthy, G. (2009): Zebrafish: a complete animal model for in vivo drug discovery and development. - Current Drug Metabolism 10: 116-124. (PMID:19275547).

[6] Chebanov, M. S., Galich, E. V. (2011): Sturgeon Hatchery Manual. - FAO Fisheries and Aquaculture Technical Paper. No. 558, ISSN 2070-7010, Ankara, Turkey. Available at: http://www.fao.org/docrep/017/i2144e/i2144e.pdf (Accessed 12.12.2017).

[7] De Oliveira, R. (2009): Zebrafish early life-stages and adults as a tool for ecotoxicology assessment. - Disertation Biology Department, University of Aveiro, Portugal. Available at: https://ria.ua.pt/bitstream/10773/8838/1/6237.pdf (Accessed 12.12.2017).

[8] Directive 2010/63/EU of the European Parliament and of the Council of 22 September 2010 on the Protection of Animals Used for Scientific Purposes. - Available at: http://eurlex.europa.eu/LexUriServ/LexUriServ.do?uri=OJ:L:2010:276:0033:0079:en:PD $\mathrm{F}$ (Accessed 12.12.2017).

[9] Directive 98/83/EC of 3 November 1998 on the quality of water intended for human consumption. - OJ L 330, 5.12.1998, p. 32-54. Available at: http://eurlex.europa.eu/legal-content/EN/TXT/PDF/?uri=CELEX:31998L0083\&from=EN (Accessed 12.12.2017).

[10] Embry, R. M., Belanger, S. E., Braunbeck, T. A., Galay-Burgos, M., Halder, M., Hinton, D. E., Léonard, M. A., Lillicrap, A., Norberg-King, T., Whale, G. (2010): The fish 
embryo toxicity test as an animal alternative method in hazard and risk assessment and scientific research. - Aquatic Toxicology 97: 79-87. Available at: https://doi.org/10.1016/j.aquatox.2009.12.008.

[11] Gessner, J., Freyhof, J., Kottelat, M. (2010): Acipenser ruthenus. - The IUCN Red List of Threatened Species 2010: e.T227A13039007. http://dx.doi.org/10.2305/IUCN.UK.20101.RLTS.T227A13039007.en.

[12] Hariharan, G., Purvaja, R., Rame, R. (2016): Environmental safety level of lead (Pb) pertaining to toxic effects on grey mullet (Mugil cephalus) and Tiger perch (Terapon jarbua). - Environmental Toxicology 31: 24-43. (http://dx.doi.org/10.1002/tox.22019)

[13] Hill, A. J., Teraoka, H., Heideman, W., Peterson, R. E. (2005): Zebrafish as a model vertebrate for investigating chemical toxicity. - Toxicology Science 86: 6-19. Available at: https://doi.org/10.1093/toxsci/kfi110.

[14] Kovács, R., Csenki, Zs., Bakos, K., Urbányi, B., Horváth, Á., Garaj-Vrhovac, V., Gajski, G., Geric, M., Negreira, N., de Alda, L., Barceló, D., Heath, E., Kosjek, T., Zegura, B., Novak, M., Zajc, I., Baebler, S., Rotter, A., Ramsak, Z., Filipic, M. (2015): Assessment of toxicity and genotoxicity of low doses of 5-fluorouracil in zebrafish (Danio rerio) twogeneration study. - Water Research 77: 201-212.

[15] Lammer, E., Carr, G. J., Wendler, K., Rawlings, J. M., Belanger, S. E., Braunbeck, T. (2009): Is the fish embryo toxicity test (FET) with the zebrafish (Danio rerio) a potential alternative for the fish acute toxicity test? - Comparative Biochemistry and Physiology Part C Toxicology and Pharmacology 149: 196-209. Available at: https://doi.org/10.1016/j.cbpc.2008.11.006.

[16] Linhartova, P., Gazo, I., Shaliutina-Kolesova, A., Hulak, M., Kaspar, V. (2015): Effects of tetrabrombisphenol A on DNA integrity, oxidative stress, and sterlet (Acipenser ruthenus) spermatozoa quality variables. - Environmental Toxicology 30: 735. Available at: http://dx.doi.org/10.1002/tox.21953.

[17] Little, E. E., Calfee, R. D., Linder, G. (2012): Toxicity of Copper to Early-life Stage Kootenai River White Sturgeon, Columbia River White Sturgeon, and Rainbow Trout. Archives of Environmental Contamination and Toxicology 63: 400-408. Available at: http://dx.doi.org/10.1007/s00244-012-9782-3.

[18] Little, E. E., Calfee, R. D., Linder, G. (2014): Toxicity of smelter slag-contaminated sediments from Upper Lake Roosevelt and associated metals to early life stage White Sturgeon (Acipenser transmontanus Richardson, 1836). - Journal of Applied Ichthyology 30: 1497-1507. Available at: http://dx.doi.org/10.1111/jai.12565.

[19] Luckenbach, T., Kilian, M., Triebskorn, R., Oberemm, A. (2001): Fish early life stage tests as a tool to assess embryotoxic potentials in small streams. - Journal of Aquatic Ecosystem Stress and Recovery 8: 355-370. Available at: https://doi.org/10.1023/A:1012976809450.

[20] McGrath, P., Li, C. Q. (2008): Zebrafish: a predictive model for assessing drug-induced toxicity. - Drug Discovery Today 13: 394-401. Available at: https://doi.org/10.1016/j.drudis.2008.03.002.

[21] McKim, J. M. (1977): Evaluation of tests with early life stages of fish for predicting longterm toxicity. - Journal of the Fisheries Research Board of Canada 34: 1148-1154. Available at: https://doi.org/10.1139/f77-172.

[22] Meyer, J. S., Adams, W. J., Deforest, D. K., Dwyer, R. L., Gensemer, R. W., Gorsuch, J. W., Johnston, R. K., Santore, R. C., Van Genderen, E. (2012): Water chemistry matters in metal-toxicity papers. - Environmental Toxicolology and Chemistry 31: 689-690. Available at: http://dx.doi.org/10.1002/etc.1773.

[23] Moșneang, C. L., Dumitrescu, E., Muselin, F., Ciulan, V., Grozea, A., Cristina, R. T. (2015a): Use of zebra fish eggs as early indicators of aquatic environmental pollution. Polish Journal of Environmental Studies 24: 2079-2085. Available at: https://doi.org/10.15244/pjoes/58649. 
[24] Moșneang, C. L., Grozea, A., Dumitrescu, E., Muselin, F., Cristina, R. T. (2015b): A correlation between two different species of fish embryos used in a freshwater qualitative pollution test. - Romanian Biotechnology Letters 20: 10352-10357. Retrieved from http://www.rombio.eu/rbl2vol20/21.pdf.

[25] Moșneang, C. L., Grozea, A., Oprescu, I., Dumitrescu, E., Muselin, F., Gál, D., Cristina, R. T. (2014): Assessment of 2,4-difluoroaniline aquatic toxicity using a zebra fish (Danio rerio) model. - Thai Journal of Veterinary Medicine 44: 445-452. Retrieved from //www.tci-thaijo.org/index.php/tjvm/article/view/25818.

[26] Noel, L., Chekri, R., Millour, S., Merlo, M., Leblanc, J. C., Guerin, T. (2013): Distribution and relationships of $\mathrm{As}, \mathrm{Cd}, \mathrm{Pb}$ and $\mathrm{Hg}$ in freshwater fish from five French fishing areas. - Chemosphere, 90: 1900-1910. Available at: https://doi.org/10.1016/j.chemosphere.2012.10.015.

[27] OECD Test No. 203. Adopted: 17 July 1992, Updated: 10 December 2009. Fish, Acute Toxicity Test. - Guidelines for the Testing of Chemicals, Section 2. Effects on Biotic Systems. 1992. (http://dx.doi.org/10.1787/9789264069961-en).

[28] OECD Test No. 210. Adopted: 26 July 2013. Guidelines for the Testing of Chemicals Fish, Early-life Stage Toxicity - Fish, Early-life Stage Toxicity Test. - 2013. (http://dx.doi.org/10.1787/9789264203785-en).

[29] OECD Test No. 236. Adopted: 26 July 2013. Fish Embryo Acute Toxicity (FET) Test. 2013. (http://dx.doi.org/10.1787/9789264203709-en).

[30] Osman, A. G., Wuertz, S., Mekkawy, I. A., Exner, H. J., Kirschbaum, F. (2007): Lead induced malformations in embryos of the African catfish Clarias gariepinus (Burchell, 1822). - Environmental Toxicology 22: 375-389. (http://dx.doi.org/10.1002/tox.20272)

[31] PubChem, Open Chemistry Database (2017): SID 24864770: Lead (IV) acetate. Available at: https://pubchem.ncbi.nlm.nih.gov/substance/24864770\#section=Top (Accessed 12.12.2017.)

[32] Rácz, G., Csenki, Zs., Kovács, R., Hegyi, Á., Baksa, F., Sujbert, L., Zsákovics, I., Kis, R., Gustafson, R., Urbányi, B., Szende, B. (2012): Subacute Toxicity Assessment of Water Disinfection Byproducts on Zebrafish. - Pathol. Oncol. Res. 18: 579-584. Available at: http://dx.doi.org/10.1007/s12253-011-9479-3.

[33] Raskovic, B., Poleksic, V., Visnjic-Jeftic, Z., Skoric, S., Gacic, Z., Djikanovic, V., Jaric, I., Lenhardt, M. (2015): Use of histopathology and elemental accumulation in different organs of two benthophagous fish species as indicators of river pollution. Environmental Toxicology 30: 1153-1161. Available at: http://dx.doi.org/10.1002/tox.21988.

[34] Reinartz, R. (2017): Sturgeons in the Danube River Biology, Status, Conservation. Retrieved from http://www.dstf.eu/assets/Uploads/documents/Sturgeons-in-the-DanubeRiverReinartz2002.pdf (Accessed 12.12.2017).

[35] Schirmer, K., Tanneberger, K., Kramer, N. I., Volker, D., Scholz, S., Hafner, C., Lee, L. E., Bols, N. C., Hermens, J. L. (2008): Developing a list of reference chemicals for testing alternatives to whole fish toxicity tests. - Aquatic Toxicology 90: 128-137. Available at: https://doi.org/10.1016/j.aquatox.2008.08.005.

[36] Scholz, S., Fischer, S., Gündel, U., Küster, E., Luckenbach, T., Voelker, D. (2008): The zebrafish embryo model in environmental risk assessment-applications beyond acute toxicity testing. - Environmental Science and Pollution Research International 15: 394404. Available at: https://doi.org/10.1007/s11356-008-0018-z.

[37] Science Direct Topics. Tricaine mesylate - an overview. Tricaine mesylate (MS-222). Available at: http://www.sciencedirect.com/topics/medicine-and-dentistry/tricainemesylate (Accessed 12.12.2017).

[38] Subotic, S., Spasic, S., Visnjic-Jeftic, Z., Hegedis, A., Krpo-Cetkovic, J., Mickovic, B., Skorić, S., Lenhardt, M. (2013): Heavy metal and trace element bioaccumulation in target tissues of four edible fish species from the Danube River (Serbia). - Ecotoxicology and Environmental Safety 98: 196-202. (https://doi.org/10.1016/j.ecoenv.2013.08.020). 
[39] Vardy, D. W., Santore, R. C., Ryan, A. C., Giesy, J. P., Hecker, M. (2014): Acute toxicity of copper, lead, cadmium, and zinc to early life stages of white sturgeon (Acipenser transmontanus) in laboratory and Columbia River water. - Environmental Science and Pollution Research 21: 8176-8187. (http://dx.doi.org/10.1007/s11356-014-2754-6).

[40] Wang, N., Ingersoll, C. G., Dorman, R. A., Brumbaugh, W. G., Mebane, C. A., Kunz, J. L., Hardesty, D. K. (2014): Chronic sensitivity of White sturgeon (Acipenser transmontanus) and rainbow trout (Oncorhynchus mykiss) to cadmium, copper, lead, or zinc in laboratory water-only exposures. - Environmental Toxicology and Chemistry 33: 2246-2258. (http://dx.doi.org/10.1002/etc.2641).

[41] Waszak, I., Dabrowska, H. (2009): Persistent organic pollutants in two fish species of Percidae and sediment from the Sulejowski reservoir in central Poland. - Chemosphere, 75: 1135-1143. (https://doi.org/10.1016/j.chemosphere.2009.03.001).

[42] Weber, D. N. (1996): Lead-induced metabolic imbalances and feeding alterations in juvenile fathead minnows (Pimephales promelas). - Environmental Toxicology 11: 4551. (http://dx.doi.org/10.1002/(SICI)1098-2256(1996)11:1<45::AID-TOX7>3.0.CO;2-9). 